\title{
GLOBAL WATER TRADE AND THE CANADIAN EXPORT REGULATIONS \\ - RECONCILING THE LEGAL QUAGMIRE WITH THE PRINCIPLE OF SUBSIDIARITY
}

\author{
Piotr Szwedo*
}

\section{Global and regional freshwater shortcomings - the need and limits of trade}

The scarcity of freshwater is a multidisciplinary phenomenon. It raises consequences of social and economical nature, to which domestic and international legal regulations must be adapted. The said scarcity should however be seen as a relative one - a regional scarcity, scarcity of certain quality of water, and scarcity over certain periods of time ${ }^{1}$. Thence, a relative character of water deficits results in attempts of providing water from the territories having its surplus.

* Jagiellonian University in Kraków, Poland. The author would like to thank the International Council for Canadian Studies for the support of this research. I am also indebted to Professors Andrew Newcombe, J. Owen Saunders and Armand de Mestral for their kind remarks during my research trip in Canada.

1 A. Hildering, International Law, Sustainable Development and Water Management, Delft 2004, at p. 95. The book is also available at http://www.eburon.nl/library/hildering. pdf; the hyperlinks provided in the text were last checked on the 12.11.2010. 
With the growing population and need of water for industrial purposes, the increasing demand resulted in international joint ventures in water trade. Singapore and Hong Kong purchase water from neighboring states, and the Caribbean islands import freshwater in bulk by tankers or barges to satisfy the growing demand resulting from the increased tourism. Water was occasionally transported from Scotland to Mallorca when droughts in Southern Spain prevented supplies from the Spanish mainland ${ }^{2}$. In 2004 Turkey and Israel reached a twenty-year agreement under which Turkey was to ship 50 million cubic meters of water annually from its Manavgat River with a prospect of constructing an underwater pipeline for the further sale 3 . "Lesotho Highlands Water" is projected as the Africa's largest water transfer scheme. It aims to transfer water from Lesotho into the industrial hearth of South Africa. Apart from water supplies to the regions of Gauteng and Johannesburg, Lesotho will importantly benefit from hydroenergy production.

Because of the infrastructural confines trade in freshwater is rather regional in nature. It requires pipelines - the modern aqueducts - or shipment by tankers. Both solutions are expensive, therefore they determine the regional character of trade in water and such character of international trade agreements in that matter. Nevertheless, the global water trade is becoming more feasible due to the development of the sea-going bags technology. Bags are constructed of industrial coated nylon fabric and they are pulled by a tug boat just below the surface of the ocean. The bags are kept afloat by air pockets and the fact that freshwater is lighter than sea water ${ }^{4}$.

2 U. Küffner, Consteted Waters: Diving or Sharing?, [in:] W. Scheumann, M. Schiffler (eds.), Water in the Middle East: Potential for Conflicts and Prospects for Cooperation, Berlin-Heidelber-New York, 1998, at p. 79.

3 A. Baillat, Global Water Policy - The New Challenges of the Commodification of Water Resources, available at http://www.allacademic.com//meta/p_mla_apa_research_citation 0/6/9/6/4/pages69643/p69643-10.php. The project seems to be suspended and the Israeli government recently opts for desalinization as a less expensive solution. Betweenwhiles, the media report about the possibility of project's revival, but due to 2010 Turkish-Israel political tensions resulting from Gaza flotilla incident, it does not seem to be a prospect perspective, see Turkey halts all state energy and water projects with Israel, available at http://www.haaretz.com/print-edition/business/turkey-halts-all-state-energy-and-waterprojects-with-israel-1.294131

4 R. Davidge, Water Exports, Newsletter June 1994, Vol. 1, No. 12 (Waterbank), available at http://www.waterbank.com/Newsletters/nws12.html. 
Therefore, the technological factors restrict the potential global freshwater market.

The constantly growing demand of freshwater and the opening of new transport possibilities made a global water trade a more feasible perspective. Canada is a relatively water-rich state. It possesses about twenty percent of the total global freshwater, a figure surpassed only by Brazil and Russia ${ }^{5}$. At the same time, it accounts only for $0,55 \%$ of the earth's population ${ }^{6}$. Much of Canada's water is locked in glacial ice. The Great Lakes region contain $20 \%$ of the world's fresh water, which is shared between eight American states and two Canadian provinces?

Canada's richness in water and water deficits at several areas of the United States resulted in different initiatives aiming in directing the water supplies towards South. Some of them were of infrastructural nature, the Great Recycling and Northern Development (GRAND) Project being the most famous of them. The aim was to separate the lower pod-shaped James Bay from Hudson Bay by a dyke, which would be converted into a large fresh water reservoir and $20 \%$ of its runoff would be directed towards the Great Lakes and then to the North American markets in greatest needs ${ }^{8}$. Mainly because of the construction costs, estimated in the 1994 of $\$ 100$ billion, the project remains inactive ${ }^{9}$. Another idea was the North American Water and Power Alliance (NAWAPA) Plan of 1964 to divert the northern rivers from Canada and Alaska down the Rocky Mountain Trench. The water would flow through a network of canals to arid regions of Canada, United States and Mexico ${ }^{10}$. However, the many technical,

5 The World's Water 2008-2009 Data, available at http://www.worldwater.org/ data20082009/Table1.pdf.

6 P. Bowal, Canadian Water: Constitution, Policy, and Trade, Michigan State Law Review 2006, Vol. 2006, No. 5, at p. 1146.

7 Protecting our Great Lakes Basin Waters, Draft Agreements to Implement the Great Lakes Charter Annex, available at http://www.ontla.on.ca/library/repository/ mon/11000/255497.pdf.

8 P. Bowal, op. cit., at p. 1149.

9 A Brief History of the Great Recycling and Northern Development (Grand) Canal Project, available at http://waterwars.wordpress.com/2006/12/02/a-brief-history-of-thegreat-recycling-and-northern-development-grand-canal-project/.

10 L.H. LaRouche, The Outline of NAWAPA, available at http://www.schillerinstitute. org/economy/phys_econ/phys_econ_nawapa_1983.html. 
economic, legal, political, and environmental challenges associated with this massive project have always appeared insurmountable ${ }^{11}$.

However, recent history knows examples of more modest but more feasible projects of water trade in North America. In 1998, the Nova Group Ltd - a company registered in Ontario applied to the authorities of the province to export Lake Superior's water in bulk to Asia. The Ontario government originally granted a permit to withdraw 10 million liters per day for sixty days a year for five years ${ }^{12}$. The permit was later rescinded after environmentalists and the federal government became involved ${ }^{13}$. The government of Ontario bowed down to the argument of uncontrolled output of freshwater from the province. The Nova Group has stated that it would seek a renewal permit if any other bulk sales from the Great Lakes were permitted ${ }^{14}$.

In 1991, British Columbia granted licenses to six Canadian companies to use super tankers to export bulk water ${ }^{15}$. One of the companies formed a joint venture with an American company, Sun Belt Inc, to ship Canadian water to Goleta, California ${ }^{16}$. For similar reasons as Ontario, the federal government imposed a moratorium on freshwater export ${ }^{17}$ and had to withdraw the concessions ${ }^{18}$. In consequence, Sun Belt deposed a claim under Chapter 11 of NAFTA ${ }^{19}$.

11 K.D. Frederick, America's Water Supply, Status and Prospects for the Future, Consequences Spring 1995, Vol. 1, No. 1, available at http://www.gcrio.org/CONSEQUENCES/spring95/ Water.html.

12 P. Bowal, op. cit., at p. 1151.

13 Ibidem.

14 B. Stupak, The Economics of, and the Demands for, Clean Water, Toledo Journal of Great Lakes' Law, Science \& Policy 2001-2002, Vol. 4, No. 3, at p. 460.

15 D. Shaw, The Specter of Water Piracy: The World Trade Organization Threatening Water Security in Developing Nations, Colorado Journal of International Environmental Law and Policy 2008, Vol. 19, No. 1, at p. 144, quoting M. Barlow, T. Clarke, Blue Gold: The Fight to Stop the Corporate Theft of the World's Water, New York 2002, at p. 134.

16 Ibidem.

17 Ch.S. Maravilla, The Canadian Bulk Water Moratorium and Its Implications for NAFTA, Currents: International Trade Law Journal 2001, Vol. 10, No. 1, at p. 29.

18 M. Tignino, D. Yared, La commercialization et la privatization de l'eau dans le cadre de l'Organisation mondiale du commerce, Revue quebecoise de droit international 2006, Vol. 19, No. 2, at p. 177.

19 Ibidem. 
The above examples demonstrate, that due to a growing demand trade in freshwater is not only a feasible perspective but also a popular phenomenon. The infrastructural confines reduce it mainly to a regional dimension, but the development of new technologies may change it into global. The evolution of the reality resulted in a need of an answer on several legal questions on freshwater trade and its permissibility under multilateral and regional trade agreements.

\section{Heterogeneous character of water trade regulations}

The goal of the international trade law, and of the World Trade Organization (hereinafter the WTO) law in particular, is to promote the liberalization of trade. Because of its specified character, the regulations do not necessarily take into account other internationally relevant values or principles. The relatively immune character of the WTO law was confirmed by the Appellate Body, which rejected the possibility of invoking the precautionary principle in the Beef Hormones dispute ${ }^{20}$. One of the arguments was, that the said principle "at least outside the field of international environmental law, still awaits authoritative formulation"21.

The regulation of international trade by a relatively isolated subsystem of international law provoked reactions of states and international community, when trade regulations interfered with other internationally relevant fields like environmental protection, human rights or health protection. The said reaction took forms of unilateral or regional character (see further pt. 3), even though the international community tried to coordinate and institutionalize the interactions between different branches of international law and to reconcile the internationally relevant values, for example through the Trade and Environment Committee ${ }^{22}$ or Commission on Intellectual Property Rights, Innovation and Public Health (CIPIH ${ }^{23}$.

20 European Communities - EC Measures Concerning Meat and Meat Products (Hormones), Report of the Appellate Body, WT/DS26/AB/R (13 February 1998), at para. 125.

21 Ibidem, at para 123.

22 http://www.wto.org/english/tratop_e/envir_e/envir_e.htm.

${ }^{23}$ http://www.who.int/intellectualproperty/en/. 
The aforementioned remarks are particularly significant for the international governance of water trade, which is a multidimensional phenomenon. Besides the applicability of the international trade law, other branches of international law related to investment, environmental protection, human rights and health protection may become relevant. Different approach to the governance of natural resources and local water surplus must also be kept in mind in the analysis of global water trade governance. The far going specialization of different branches of international law is moreover complicated because of the existence of the domestic law having often a transnational effect on trade. Therefore an objective specialization of international law coexists with multilevel governance of water trade matters.

\section{Multilevel character of water trade regulations}

The fundamental question in water trade is whether it should be treated as any other good or product. The law of WTO or NAFTA gives no answer to this question. The legal lacuna provides a large field of speculation. Even if the nonobservance of the international law may not be justified by the rules of domestic law (see pt. 4), the law of the states may have a transnational character and shape the international practice. They also may determine states' unilateral acts, which are internationally relevant.

\subsection{Universal treaties - the WTO agreements}

The commodification of water is the key issue in its tradability. The General Agreement on Tariffs and Trade (hereinafter the GATT) ${ }^{24}$ does not contain any regulation requiring a special treatment of water, which would preclude its character of "good" under the WTO law. Moreover, the Harmonized Commodity Coding System, elaborated by the World Customs Organization on which the WTO members tariff schedules are

24 General Agreement on Tariffs and Trade, 30.10.1947, United Nations Treaty Series, Vol. 55, No. 187. 
based" ${ }^{25}$, contains a 22.01 position: "Waters, including natural or artificial mineral waters and $[. .$.$] ther water" 26$.

Art. XI of GATT prohibits quantitative export restrictions of "any product destined for the territory of any other contracting party". Due to the principles of national treatment and most-favored-nation, a WTO member should not limit the export or restrict it only to the domestic or selected foreign markets. Assuming that bulk water is a "good", states a priori should not restrict its export unless one of the GATT exceptions applies. Art. XX stipulates, that:

"[s]ubject to the requirement that such measures are not applied in a manner which would constitute a means of arbitrary or unjustifiable discrimination between countries where the same conditions prevail, or a disguised restriction on international trade, nothing in this Agreement shall be construed to prevent the adoption or enforcement by any contracting party of measures: [...] (g) relating to the conservation of exhaustible natural resources if such measures are made effective in conjunction with restrictions on domestic production or consumption".

The Appellate Body in the Reformulated Gasoline decision concluded that "clean air" was an "exhaustible natural resource"27. It follows that, under this standard the freshwater should be treated similarly, what prejudges the applicability of Article XX $(\mathrm{g})$. Application of this exception clause requires however a "restriction on domestic production or consumption". Therefore once the water is traded, limitation of its export would also require a reduction of domestic production or consumption. Article XX(g) reflects the omnipresent idea of nondiscrimination in GATT and could not serve as a sufficient legal defense against the Canada's deprivation of its "blue gold".

25 See GATT Concessions under the Harmonized Commodity Description and Coding System - Revision, L/5470/Rev.1, 30.6.1983, available at http://www.wto.org/gatt_docs/ English/SULPDF/91000350.pdf.

26 http://www.wcoomd.org/files/1.\%20Public\%20files/PDFandDocuments/ HarmonizedSystem/2007/0422-2007E.pdf.

27 United States - Standards for Reformulated and Conventional Gasoline, Report of the Appellate Body, WT/DS2/AB/R (20.5.1996). 
In order to preserve its entire sovereignty over water, states (like Canada) not willing to share and export their resources opt rather for a full exception of the GATT's applicability by demonstrating a distinct than a "good" or "product" character of water under the GATT, than base their argumentation on Article XX(g). The full exception could be argued under the textual approach to the GATT. The term "product" is not defined in the Agreement, thus its meaning should be understood commonly. A product is a thing "produced", which must first undergo a process that somehow transforms the resource into an item of commerce ${ }^{28}$. Proponents of this view assert that since water in its natural state is an unexploited resource, like oil and gas in the ground, it is not a "product" and therefore not a subject to GATT provisions ${ }^{29}$.

The preceding point of view does not necessarily have to be shared. The legal lacuna leaves enough room for an alternative interpretation. The project on export of water between two WTO members - Turkey and Israel (see pt. 1) - was based on an international agreement, which emphasized the commercial nature of international water transfers and created a legal regime of state - to - state water exports ${ }^{30}$. On the occasion of the signature of the agreement the spokesman of the Turkish Minister of Foreign Affairs stated that "it turns water into an internationally accepted 'commodity' [...] and that Turkey hopes to sell water to other countries" 31 .

\subsection{Regional treaties - NAFTA}

Apart from its WTO membership, Canada is a party to a regional North American Free Trade Agreement ${ }^{32}$ (hereinafter NAFTA). As GATT in Article XI, NAFTA contains a prohibition of quantitative restriction

28 S. Gordon, Canada's Fresh Water and NAFTA: Clearing the Muddied Waters, Dalhousie Journal of Legal Studies 2006, Vol. 15, at p. 77.

29 Ibidem; J.W. Boyd, Canada's Position Regarding an Emerging International Fresh Water Market with Respect to the North American Free Trade Agreement, NAFTA Law \& Business Review of the Americas 1999, Vol. 5, No. 2, at p. 335.

30 M. Tignino, D. Yared, La commercialization, at p. 175.

31 Israel signs agreement to buy water from Turkey, March 2004, http://www. uswaternews.com/archives/arcglobal/4israsign3.html.

32 International Legal Materials 1993, Vol. 32, No. 2, at p. 289. 
(art. 30933) and includes no textual indication on whether water is a "product". The commentators usually agree that water incorporated into products such as beverages convert it into a good ${ }^{34}$. The labor and mechanical input of packaging the resource, such as in filtering, testing, and bottling water, thus removing it from its "pristine" bulk state, would serve to convert it into a "good" for trade purposes ${ }^{35}$. As J. Johnson explained: "for water to be a product, something must be done to it". It must be gathered, stored, transported, graded, treated, bottled or otherwise packaged. Bottled water is clearly a product. Water in pipeline or tanker is as much a product as is oil in a pipeline or tanker. Water in its natural state, however, is not a product any more than oil in the ground ${ }^{36}$. Some commentators see no clear textual argument and doubt on the exclusion of water from the ambient of NAFTA ${ }^{37}$. Assuming that NAFTA is applicable to water would require the member states to share their water resources for export if water was traded internally. Under Articles 315 of NAFTA, Canada is precluded from ever reducing "the proportion of total exports shipments of the specific good [in this case water] made available to that party relative to total supply". Another way of stating this is to say that the US is entitled to a proportional share of Canadian water resources in perpetuity: once the tap is turned on, it stays on. Flows may be reduced but only if water is also rationed to Canadian consumers and companies ${ }^{38}$.

33 "Except as otherwise provided in this Agreement, no Party may adopt or maintain any prohibition or restriction on the importation of any good of another Party or on the exportation or sale for export of any good destined for the territory of another Party, except in accordance with Article XI of the GATT [...]".

34 P. Bowal, op. cit., at p. 1170.

35 J. Johnson, Water Exports and Free Trade: Another Perspective, [in:] A.L.C. De Mestral, D.M. Leith (eds.), 'Canadian Water Exports and Free Trade', Ottawa 1989, at p. 28, quoted in P. Bowal, op. cit., at p. 1170.

36 Ibidem, at p. 1171.

37 See S. Shrybman, A Legal Opinion Concerning Water Export Controls and Canadian Obligations under NAFTA and the WTO, West Coast Environmental Law 15 September 1999, available at http://wcel.org/sites/default/files/publications/A\%20Legal\%20 Opinion\%20Concerning\%20Water\%20Export\%20Controls\%20and\%20Canadian\%20 Obligations\%20Under\%20NAFTA.pdf.

38 Ibidem. 
The above controversy on the application of NAFTA to water in its natural state provoked a reaction of the three future member states' governments, which in order to finalize the negotiations made a following declaration on water:

„[I]n order to correct the false interpretations [the governments] agreed to state, that:

The NAFTA creates no rights to the natural water resources of any Party to the Agreement unless water, in any form, has entered into commerce and become a good or product, it is not covered by the provisions of any trade agreement including the NAFTA. And nothing in the NAFTA would oblige any NAFTA Party to either exploit its water for commercial use, or to begin exporting water in any form. Water in its natural state in lakes, rivers, reservoirs, aquifers, water basins and the like is not a good or product, is not traded, and therefore is not and never has been subject to the terms of any trade agreement" ${ }^{\prime \prime}$.

The intentions of governments are clear and cover not only NAFTA but also implicitly other trade agreements such as GATT. They also separated the trade from water issues by stating, that:

„International rights and obligations respecting water in its natural state are contained in separate treaties and agreements negotiated for that purpose. Examples are the United States-Canada Boundary Waters Treaty of 1909 and the 1944 Boundary Waters Treaty between Mexico and the United States" ${ }^{\prime 4}$.

The declaration has only a limited scope of applicability. It should be treated as an "instrument which was made by one or more parties in connection with the conclusion of the treaty and accepted by theother parties as an instrument related to the treaty" - "context" which, according to the Article 31 of the Vienna Convention on the Law of Treaties needs to be taken into account in the process of interpretation of NAFTA and of GATT between the NAFTA parties. However, it is out of the context in the

391993 Statement by the Governments of Canada, Mexico and the United States, available at the website of the Canadian Intergovernmental Conference Secretariat, http://www.scics.gc.ca/cinfo99/83067000_e.html\#statement.

40 Ibidem. 
case of application of the GATT between a NAFTA member and a third state. The said declaration may not become a part of interpretational context in relations with the third state without its consent ${ }^{41}$.

Even if modification of the state parties' rights and obligation is permissible under Article 41 of the Vienna Convention on the Law of Treaties, the WTO law substantially limits the scope of maneuver. According to the Agreement Establishing the WTO, GATT constitutes its "integral part" and is "binding on all its members" (Article II(2)). More importantly, each member must "ensure the conformity of its laws, regulations and administrative procedures with its obligations as provided in the annexed Agreements" (Article XVI(4)). According to this provision, the WTO members should not adapt the multilateral agreement to their domestic law, but their internal regulations should be adjusted to WTO obligations. The potential amendments or interpretations of the agreements are entrusted to the Ministerial Conference or General Council, both composed of all WTO members (Articles IX(2) and X). Regardless of whether NAFTA parties can condition their NAFTA obligations by issuing a joint statement of understanding, it is unlikely that WTO members can condition their WTO obligations so easily ${ }^{42}$.

The above arguments based on WTO law are however irrelevant assuming that the GATT does not apply to freshwater at all as it is not a product. The latter decision would require an interpretation of a legal lacuna. The governments of NAFTA members could argue, that they do not modify, adapt or amend their obligation, but only clarify their existing content. For example, the United States Trade Representative took a position that a restriction on bulk water exports "would not run afoul of obligations imposed by international trade agreements". All governments have "sovereign interests" in the management of watercourses in their territories, while international watercourses are governed by a

„long-standing well-developed body of international law [...] on the nonnavigational uses of watercourses. [...] This is not to say that the WTO

41 See Draft Articles on the Law of Treaties with commentaries, Yearbook of the International Law Commission 1966, Vol. II, at p. 221.

42 R. Girouard, Water Export Restrictions: A Case Study of WTO Dispute Settlement Strategies and Outcomes, Georgetown International Environmental Law Review 2002-2003, Vol. 15, No. 2, at p. 259. 
rules could never apply to water which has been extracted from watercourse and actually traded in international commerce. But the WTO simply has nothing to say regarding the basic decision by governments on whether to permit the extraction of water from lakes and rivers in their territory" ${ }^{\prime 3}$.

The principle of sovereignty over state's natural resources has no formal priority over the obligations stemming out from the free trade agreements and it is simply unclear, whether a state which extracts water for its national market has a competence to ban its export without reducing its own consumption.

\subsection{Domestic constitutional law}

Water or right to water was an object of direct or indirect regulation of constitutional law. Interestingly, South Africa, which is developing a water transfer scheme with Lesotho (see Section 1 above), makes direct reference to water and recognizes a right to water in Section 27 of its Constitution ${ }^{44}$. The right to water was also recognized by the Belgian Constitutional Court as an economic, social and cultural right guaranteed by the Belgian Constitution ${ }^{45}$. It was also derived from Article 21 of the Constitution of India, which guarantees right to life ${ }^{46}$.

In federal states one of the primal roles of the constitution is to distribute the legislative power between federal and provincial legislature.

43 Letter from the Deputy United States Trade Representative (November 24, 1999), Protection of the Waters of the Great Lakes Final Report to the Governments of Canada and the United States, February 22, 2000.

44 "Health care, food, water and social security

1. Everyone has the right to have access to: (...)

b. sufficient food and water; (...)

2. The state must take reasonable legislative and other measures, within its available resources, to achieve the progressive realization of each of these rights."

The text of South African Constitution is available at the website of South African Government Information: http://www.info.gov.za/documents/constitution/1996/96cons2. htm\#26.

45 http://www.righttowater.info/code/Legislation_5.asp.

46 V. Narain, Water as a Fundamental Right: A Perspective from India, Vermont Law Review 2009-2010, Vol. 34, No. 4, at p. 920. The Constitution of India is available at http://lawmin.nic.in/coi/coiason29july08.pdf 
The Canadian Constitution Act of 1867 does not directly refer to water. Sections 91 and 92 segregate Canada's sovereign powers between the provincial and federal governments. It must however be kept in mind that the division is not dichotomous. Some functional areas are subject to both federal and provincial legislative control. Since the use of water resources has both national and provincial implications, both levels of government may lay claim to legislative competence within their respective spheres ${ }^{47}$. Certain water related matters were already an object of review by Canadian appellate decisions ${ }^{48}$. As such, any legislation may be multi-faced and applicable to heads of power under both legislatures ${ }^{49}$.

\subsection{Federal statutory law}

Section 91(10) of the Canadian Constitutional Act confers to the federal government the power over navigation. The competence has been broadly construed to extend beyond navigable waters to works of navigation and harbors and admiralty law ${ }^{50}$. Section 108 vests power in the federal government over "canals, with lands and water power connected therewith, public harbors, river and lake improvements... and lands set apart for general public purposes". This provision does not convey the watercourses to federal government but merely the power to improve them. This is however a competence indispensable to run the water trade projects.

The federal government of Canada attempted to implement legislation that would effectively prevent the export of bulk water. The Federal Water Policy of 1987 stated that the federal government would take all possible measures within the limits of its constitutional authority to prohibit the

47 D. Johansen, Water Exports and the NAFTA, Government of Canada Publications, 8.3.1999, available at http://dsp-psd.pwgsc.gc.ca/Collection-R/LoPBdP/BP/prb0041-e.htm.

48 Citizens Ins. Co. v. Parsons, [1881] 7 App. Cas. 96; Friends of Oldman River Soc'y v. Canada (Minister of Transport), [1992] S.C.R. 3; Hodge v. The Queen [1883] 9 App. Cas. 117 at 130; R. v. Hydro Quebec [1997] S.C.R. 213; R. v. Sparrow [1990] S.C.R. 1075 referred to in P. Bowal, op. cit., at p. 1162 at footnote no. 140.

49 P. Bowal, op. cit., at p. 1162 quoting N. Finkelstein, R. Urman, Constitutional Jurisdiction in Relation to Water Law, Canadian Bar Association National Symposium on Water Law, 9-10.4.1999, at p. 1.

50 Ibidem, at footnote 50 , at p. 8 . 
export of Canadian water by interbasin diversions ${ }^{51}$. This attempt was however legally ineffective, because it was just a policy and therefore had no legal consequences upon a violation of any administrative obligations ${ }^{52}$. The second attempt was the Canada Water Preservation Act of 1988, which would prohibit the large-scale, and limit the small-scale, export of Canadian fresh water. This bill however, was tabled for later reconsideration because of an ensuing federal elections ${ }^{53}$. It was later reintroduced as Bill C-535, an Act respecting the preservation of Canada's water resources, but was not voted by the Canadian Parliament ${ }^{54}$. In 1993 Canada issued the North American Free Trade Implementation Act, which limited the scope of the agreement only to bottled water ${ }^{55}$. Nonetheless, this domestic legal act could only amount to an "instrument which was made by one [party] in connection with the conclusion of the [NAFTA]" and would have to be "accepted by the other parties as an instrument related to the treaty" ${ }^{\prime 6}$ in order to be given legal force. Lack of such binding effect resulted in issuance of the Canada-United States-Mexico Declaration (see section 3.2).

On 11.12.1999, the Parliament of Canada unanimously enacted a moratorium on all potential bulk exports of Canadian freshwater ${ }^{57}$. The aim was inter alia to amend the International Boundary Waters Treaty Act in order to give the government of Canada the regulatory power to prohibit bulk freshwater exports from boundary waters with the United States like the Great Lakes and other sources and to induce those provinces and territories that have not yet adopted a moratorium on bulk water exports to do so in the near future ${ }^{58}$. Such a situation was a result of the overlapping scope of federal and provincial competences on the matters related to water.

51 Available at http://www.ec.gc.ca/eau-water/default.asp?lang=En\&n=D11549FA-1.

52 J.W. Boyd, op. cit., 340.

53 Ibidem.

54 See http://openparliament.ca/bills/1783/.

55 Para 7(1), (2), available at http://laws.justice.gc.ca/PDF/Statute/N/N-23.8.pdf.

56 See art. 31(2)(b) of the Vienna Convention on the Law of Treaties.

57 Ch.S. Maravilla, op. cit., at p. 29.

58 Canadian Government: Strategy launched to prohibit the bulk removal of Canadian water, including water for export, available at http://www.highbeam.com/doc/1G1-53866913. html. 


\subsection{Provincial law}

According to the "Strategy to Protect Canadian Water" provinces have the primary responsibility for water management and the Government of Canada ${ }^{59}$. Inland waters, such as harbors, bays, estuaries, and other water wholly within provincial boundaries and encompassed by its land mass are subject to provincial jurisdiction ${ }^{60}$. Section 92A of the Canadian Constitution conveys the competence to regulate matters related to exploitation, development, conservation and management of natural resources in the province to provincial legislatures. Moreover regulation of sites and facilities for the generation and production of electrical energy is also a provincial matter.

The Constitution also entrusts the power to make laws on intra - Canadian export of natural resources to provinces. Such regulations may not provide for discrimination in prices or in supplies. However the extra - Canadian trade and commerce is a federal matter ${ }^{61}$. Therefore the possibility of exporting fresh water could be taken out of the hands of provincial governments ${ }^{62}$. In matters respecting environment and trade, the division of competences is also not dichotomous: both the federal and provincial governments can create legislation ${ }^{63}$.

In 1980 many Canadian provincial decision makers were favorable to water export from their provinces. The Prime Minister of Quebec R. Bourassa was also openly in support of a proposed project to build a canal from the James Bay to the US Southwest in order to move water into that increasingly arid part of the United States. In March 1986, British Columbia's provincial government gave the green light to W.C.W. Enterprises, through granting the exclusive rights to ship water from Link Lake at Ocean Falls, which is replenished by a glacier,

59 Canada, Department of Foreign Affairs and International Trade, A Strategy to Protect Canadian Water, backgrounder, 10.2.1999 quoted in D. Johansen, op. cit.

60 P. Bowal, op. cit., at p. 1162 quoting P.W. Hogg, Constitutional Law of Canada, Toronto 1997, at p. 319.

61 See Section 91(2) of the Canadian Constitutional Act.

62 See J.W. Boyd, op. cit., at p. 339.

63 Id. quoting P.W. Hogg, Constitutional Law of Canada, Toronto 1985, at p. 317. 
to the United States ${ }^{64}$. However, the issuance by the government of Ontario of water export license to Nova Group (see Section 1 above) resulted in more controversy. The water was to be extracted from one of the Great Lakes, the Lake Superior, which is to be administered by US-Canadian International Joint Commission established on the ground of the Canada-U.S. Boundary Waters Treaty Act of $1909^{65}$. Even if its decisions are not binding, a unilateral decision without consulting the Commission could amount to a procedural breach of the obligation to consult the boundary waters issues ${ }^{66}$. In consequence the license was formally cancelled by the provincial government based on the new provincial water transfer policy. The Ontario Provincial Government enacted a surface water policy, which generally opposes any proposals to divert water and stresses the need to preserve water quantity to sustain ecosystem integrity ${ }^{67}$.

The Canadian provinces' water policy is not necessarily identical. At the time of Nova Group controversy in Ontario, the Newfoundland Provincial Government accepted an application from the McCurdy Group of Companies to export its freshwater. The Newfoundland's Department of Environment and Labour confirmed the Province's will to fulfill their commitments and to treat water as any other resource ${ }^{68}$. The Newfoundland's example indicates that provinces and federal government not necessarily have to work together. The Canadian federal government's memorandum, even in a not binding form, was an attempt to harmonize Canada's water export policy ${ }^{69}$.

64 Ch.S. Maravilla, op. cit., at p. 31.

65 International Boundary Waters Treaty Act (R.S., 1985, c. I-17), available at http:// laws.justice.gc.ca/en/ShowTdm/cs/I-17/en.

66 See Article IX of the International Boundary Waters Treaty Act.

67 Since 1999, water transfer out of Ontario's main basins have been prohibited subject to several exceptions, see http://www.waterpolicy.ca/comparison.php?ids=9.

68 J.W. Boyd, op. cit., 344.

${ }^{69}$ C. Hill, K. Furlog, K. Bakker and A. Cohen in their screening of Canadian provinces' water policy opted for their greater harmonization, what in many cases would imply greater federal involvement, see Harmonization Versus Subsidiarity in Water Governance: A review of Water Governance and Legislation in the Canadian Provinces and Territories, Canadian Water Resources Journal 2008, Vol. 33, No. 4, at pp. 315-332. 


\section{Multilevel regulations and the role of the principle of subsidiarity}

The roots of the principle of subsidiarity should be traced back in the Old Testament. In the Book of Exodus Moses, who was charged with all kinds of tasks in the governance of the chosen people, was advised by his father-in-law Jethro to delegate his judicial power and nominate judges, who would have a competence to deal with ordinary cases and would refer to Moses only the "great matters"70. This concept is also present in th antique philosophy of Plato ${ }^{71}$ and Aristotle ${ }^{72}$. An individual is not able to perform all its tasks on its own and naturally forms groupings like family, guilds, villages and cities. The power should be distributed in such a manner as to avoid tyranny. In small groupings individuals have more influence on the acts performed by the authorities. Therefore individuals should enjoy as much liberty as possible and the authorities should not be conferred more power than it is indispensable to fulfill their entrusted tasks. The principle of subsidiarity was later developed by the teachings of the Roman Catholic Church: encyclicals of Leo XIII Rerum Novarum (1891) ${ }^{73}$, of Pius XII Quadragesimo anno (1931) $)^{74}$ and John Paul II Centesimus annus (1991) ${ }^{75}$. The teachings of the Magisterium emphasize the crucial role of state in enabling the development of a human while respecting its autonomy and the autonomy of smaller social units such as family.

The principle of subsidiarity, apart from its philosophical and social dimension, acquired also its legal importance. It was broadly discussed

70 "[T]hou shalt provide out of all the people able men, such as fear God, men of truth, hating covetousness and place [such] over them, [to be] rulers of thousands, [and] rulers of hundreds, rulers of fifties, and rulers of tens. And let them judge the people at all seasons: and it shall be, [that] every great matter they shall bring unto thee, but every small matter they shall judge: so shall it be easier for thyself, and they shall bear [the burden] with thee", Book of Exodus 18:21, 22.

71 Plato, The Republic, Book II, 369 b-c.

72 Aristotle, Politics, Book I, Part 2.

73 See para. 13.

74 See para. 79.

75 See para. 15. 
as a fundament of constitutional and EU law. The $10^{\text {th }}$ Amendment to the Constitution of the United States of America ${ }^{76}$ and Article 72 of the Basic Law of Germany ${ }^{77}$ contain a principle of division of powers between states/lands and federal authorities and play a similar function. The Canadian Constitutional Act contains a clause granting to the provinces the competence to regulate "Generally all Matters of a merely local or private Nature in the Province"78. The modern constitutions of unitary states, like the Republic of Poland, directly set up this rule as being a fundamental in the distribution of power ${ }^{79}$. Article 5 of the Treaty on the European Union ${ }^{80}$ also formulates the principle of subsidiarity as

76 The powers not delegated to the United States by the Constitution, nor prohibited by it to the States, are reserved to the States respectively, or to the people.

77 Article 72 [Concurrent legislative power of the Federation definition]

„(1) On matters within the concurrent legislative power, the Länder shall have power to legislate so long as and to the extent that the Federation has not exercised its legislative power by enacting a law.

(2) The Federation shall have the right to legislate on these matters if and to the extent that the establishment of equal living conditions throughout the federal territory or the maintenance of legal or economic unity renders federal regulation necessary in the national interest.

(3) A federal law may provide that federal legislation that is no longer necessary within the meaning of paragraph (2) of this Article may be superseded by Land law".

Basic Law for the Federal Republic of Germany (Grundgesetz), in the version promulgated on 23.5.1949 (first issue of the Federal Law Gazette, dated 23.5.1949), as amended up to and including 20.12.1993; English translation available at http://www. iuscomp.org/gla/statutes/GG.htm\#72.

78 See Constitution act of 1982, art. 92(16).

79 "We the Polish Nation - all citizens of the Republic, [h] ereby establish this Constitution of the Republic of Poland as the basic law for the State, based on [...] the principle of subsidiarity in the strengthening the powers of citizens and their communities." Preamble of the Constitution of the Republic of Poland, Polish OJ 1997, No. 78, Item 483, English translation available at http://www.sejm.gov.pl/prawo/konst/ angielski/kon1.htm.

80 "1. The limits of Union competences are governed by the principle of conferral. The use of Union competences is governed by the principles of subsidiarity and proportionality. [...] 3. Under the principle of subsidiarity, in areas which do not fall within its exclusive competence, the Union shall act only if and insofar as the objectives of the proposed action cannot be sufficiently achieved by the Member States, either at central level or at regional and local level, but can rather, by reason of the scale or effects of the proposed action, be better achieved at Union level.", Consolidated version of the Treaty on European Union, O. J. 9.5.2008, C-115. 
a principle of division of powers between the Union and the member states and which entrusts to the Union the competences and tasks, which may be better achieved on the European than on domestic level.

The obligation of a state to limit its intervention to "lower" form of social organization might be referred as the "negative" dimension of the principle of subsidiarity. However, when the "lower" form of social organization cannot achieve their ends by themselves, the intervention of the state is justified, what constitutes the "positive dimension" of the principle. However, subsidiarity insists not only that the state may intervene in such situations, but that it has "an inherent right" to concern itself with the common good ${ }^{81}$. The two dimensions could be referred to international relations. Problems like climate warming, water scarcity, global security, financial crises, combat against money laundering require universal approach and globally administered actions, or rather a globally coordinated multilevel involvement of different nature.

The subsidiarity approach was already proposed as a method of analysis of states' choice of bilateral, regional, or plurilateral regimes over multilateral ones in the international economic law. A. Reich argued, that as well-functioning provincial and local governments may serve as building blocks for a leaner, better functioning, and more democratic central government, bilateral and regional regimes may serve as important building blocks for leaner, better functioning, and more democratic multilateral organization ${ }^{82}$. The Author admits that in the trade context, the subsidiarity approach turns the GATT Article XXIV on its head by making bilateral arrangements the default and engaging multilateralism only where goals could not be attained on a regional or bilateral basis ${ }^{83}$.

81 See P.G. Carozza, Subsidiarity as a Structural Principle of International Human Rights Law, American Journal of International Law 2003, Vol. 97, No. 1, at p. 44, quoting B. Llamazon, Subsidiarity: The Term, Its Metaphysics and Use, Aquinas: Rivista Internazionale Di Filosofia 1978, Vol. 21, at p. 47.

82 A. Reich, Bilateralism versus Multilateralism in International Economic Law: Applying the Principle of Subsidiarity, University of Toronto Law Journal 2010, Vol. 60, No. 2, at p. 263.

83 Id., at p. 286. 
Subsidiarity as a model of administration was advocated by United Nations documents ${ }^{84}$, World Bank action plans ${ }^{85}$ and NGO reports ${ }^{86}$. Even if those international organizations called mostly for a recognition of subsidiarity as an infra-state management rule, the said principle is relevant in international law itself. It was mentioned in the report of the International Law Commission on the Fragmentation of International Law regarding the Article 52(2) of the Charter of the United Nations ${ }^{87}$, which induces to "make every effort to achieve pacific settlement of local disputes through [...] regional arrangements or by [...] regional agencies before referring them to the Security Council". According to the Reporters "Chapter VIII [of the Charter of the United Nations] should be seen as a set of functional provisions that seek the most appropriate level for dealing with particular issues with due regard to issues of "subsidiarity"' 88 . Principle of subsidiarity and complementarity also governs the admissibility of cases before international courts and tribunals in their relation to domestic judicial organs. According to Article 17 of the Rome Statute of the International Criminal Court ${ }^{89}$, " $t]$ he case is being investigated or prosecuted by a State which has jurisdiction over it, unless the State is unwilling or unable genuinely to carry out the investigation or prosecution" ${ }^{\prime 0}$. Similarly under Article 35 of the European Convention for the Protection of Human Rights and

84 United Nations Centre for Human Settlements (Habitat), Towards a World Charter of Local Self-Government The Origins, Aims and Proposed Preparation Process for the World Charter, available at http://www.gdrc.org/u-gov/charter.html.

85 Decentralization \& Subnational Regional Economics, Intergovernmental Fiscal Relations, available at http://www1.worldbank.org/publicsector/decentralization/fiscal.htm.

86 International Council on Human Rights Policy, Local Rule Decentralization and Human Rights, available at http://www.reliefweb.int/rw/lib.nsf/db900sid/JBRN7LPK5G/\$file/ICHRP_Jan2002.pdf?openelement.

871 United Nations Treaty Series XVI.

88 Fragmentation of International Law; Difficulties Arising from the Diversification and Expansion of International Law. Report of the Study Group of the International Law Commission, ILC Report of the Work of its Fifty-eight session, Official Records of the General Assembly, Sixty-first session 2006, doc. A/CN.4/L.682, at para. 217.

892187 United Nations Treaty Series 90.

90 See also J.M. Czarnetzky, R.J. Rychlak, An Empire of Law: Legalism and the International Criminal Court, Notre Dame Law Review 2003-2004, Vol. 79, No. 1, at pp. 55 . 
Fundamental Freedoms ${ }^{91}$, "[the] Court may only deal with the matter after all domestic remedies have been exhausted". Article 41(1)(c) of the International Covenant on Civil and Political Rights plays a similar function ${ }^{92}$.

Apart from the function of the allocation of authority and jurisdiction the subsidiarity principle may also have a distinct meaning in the interpretation of treaties. A need for an approach based on subsidiarity was convincingly argued by P. G. Carozza in his analysis of the dialectic between universal human rights norms and legitimate claims to pluralism ${ }^{93}$. A notable example of the "negative dimension" of the principle of subsidiarity could be associated with the doctrine of the "margin of appreciation" developed by the European Court of Human Rights ${ }^{94}$. In its simplest form, the principle of subsidiarity holds that international human rights standards are best implemented at the lowest level of government that can effectuate those standards ${ }^{95}$. Thus, before a supranational or multinational body renders a decision on a matter of international human rights, it must first be assured that the domestic government at issue has been given an opportunity to remedy the situation. Moreover, even once a human rights matter has been considered or adjudicated by the supranational body, the principle of subsidiarity is thought to generally require that the decision as to remedial measures is best left to the domestic government ${ }^{96}$. Principles similar to the "margin of appreciation" doctrine could potentially be applied by other international courts in allowing latitude to national governments in interpreting international agreements in light of local needs. For example, the Appellate Body of the WTO in the beef hormone case $^{97}$ reversed the panel's finding that national health and safety measures were required by the trade agreements to closely "conform

91213 United Nations Treaty Series 221.

92999 United Nations Treaty Series 171.

93 P.G. Carozza, op. cit., at p. 40.

94 Id.

95 W.M. Carter Jr., Rethinking Subsidiarity in International Human Right Adjudication, Hamline Journal of Public Law and Policy 2008-2009, Vol. 30, No. 1, at p. 319.

96 Id.

97 EC Measures Concerning Meat and Meat Products (Hormones), Report of the Appellate Body, WT/DS26/AB/R, WT/DS48/AB/R, (Jan. 16, 1998), at paras 155-156. 
to" independent international standards on safety, endorsing a looser standard; although the WTO did not call this a margin of appreciation, the concept was similar ${ }^{98}$.

In the Rio Declaration on Environment and Development the international community stated that "[e]nvironmental issues are best handled with participation of all concerned citizens, at the relevant level". It reflects the Aristotelian idea subsidiarity, that the smaller the association, the greater the scope of individual choice ${ }^{99}$. The Declaration is not legally binding instrument and its aim is to "guide the international community in its efforts to achieve sustainable development" ${ }^{100}$. In the Report of the Secretary General it was admitted that "[t]he legal status of each of the principles [enumerated in the Declaration - P. Sz.] varies considerably. Some are firmly established in international law, while others are only in the process of gaining acceptance"101. Nevertheless, the principle of public participation and subsidiarity - in both positive and negative dimensions - was reaffirmed in the Article 3 of the United Nations Convention to Combat Desertification in Countries Experiencing Serious Drought and/or Desertification, Particularly in Africa by stating that

"programmes to combat desertification and/or mitigate the effects of drought are taken with the participation of populations and local communities and that an enabling environment is created at higher levels to facilitate action at national and local levels [...], the Parties should [...] improve cooperation and coordination at subregional, regional and international levels"102.

98 Jenny S. Martinez, Towards an International Judicial System, Stanford Law Review 2003-2004, Vol. 56, No. 2, at p. 519.

99 See E. Popławska, The Principle of Subsidiarity under the 1997 Constitution of Poland, Saint Louis - Warsaw Transatlantic Law Journal 1997, at p. 108.

100 Declaration on Environment and Development, Principle 10, UN Doc. A/CONF.151/5/Rev.1 (1992), available at http://www.unep.org/Documents/Default.asp? DocumentID=78\&ArticleID=1163.

101 United Nations Economic and Social Council, Commission on Sustainable Development, Fifth session, 7-25 April 1997, E/CN.171997/8, available at http://www. un.org/esa/documents/ecosoc/cn17/1997/ecn171997-8.htm.

102 U.N. Doc. A/AC.241/15/Rev.7., 1954 United Nations Treaty Series, 33480. 
A need of multilevel approach to water management was confirmed by the Agenda 21 - the United Nations Action Plan on sustainable development ${ }^{103}$. The document emphasized a need of holistic and multisectoral approach to protection of quality and supply of freshwater resources. It would require a cooperation between different levels of governance: local, national, regional and global. Moreover it would require a development of water-related institutions at the said levels ${ }^{104}$.

Nevertheless, the international public law is composed of sources formally having the same importance in their hierarchy. A universal treaty has no formal priority over a regional or bilateral treaty. The principle of pacta sunt servanda, as expressed in the Article 26 of the Vienna Convention on the Law of Treaties followed by the Article 27 provide that the internal law is de iure non-relevant in the observance of international $\operatorname{law}^{105}$. The status of the declaration of the governments of United States, Canada and Mexico on the non-applicability of the NAFTA and implicitly the GATT to freshwater is ambiguous. Assuming that the NAFTA and the GATT are a priori applicable to freshwater it could be seen as an amendment of NAFTA and an implicit modification of the GATT under Article 41 of the Vienna Convention on the law of treaties. The parties intent was however to "correct the false interpretations" (see Section 3.2.). Therefore it must be assumed, that their intent was not to amend or modify the treaty but to assure its interpretation in accordance with the state parties' will. It however must be kept in mind that neither the NAFTA nor the GATT is a pure traité-contrat but a lawmaking treaty and its interpretation by the other subjects, including the private parties could differ from the parties' will.

However the lack of hierarchy of legal sources does not preclude a hierarchy of legal norms. As the hierarchy of sources is based on purely formal criteria, the hierarchy of norms is a result of their content. The principle of subsidiarity does not create a formal theory

103 Available at http://www.un.org/esa/dsd/agenda21/?utm_source=OldRedirect\&utm_ medium=redirect\&utm_content=dsd\&utm_campaign=OldRedirect.

104 United Nations Conference on Environment \& Development, Rio de Janerio, Brazil, 3 to 14.6.1992, AGENDA 21, paras. 18.7, 18.9, 18.12, 18.21, 18.36, 18.50, available at http://www.un.org/esa/sustdev/documents/agenda21/english/Agenda21.pdf.

105 Art. 27: "A party may not invoke the provisions of its internal law as justification for its failure to perform a treaty. (...)”, 1155 United Nations Treaty Series, 331. 
of sources, which would result in an automatic prevalence of a regional treaty over a universal one, similarly as the provincial law does not automatically prevail over the federal law. The principle of subsidiarity in international law is rather related to the levels of authority, according to which the decisions should be taken and implemented as close to the citizen as possible. Therefore, even if the national law remains formally irrelevant in the fulfillment of international law, the efficient management of multidimensional problems, like water scarcity and water trade, requires a cooperation between different levels of authority. Principle of subsidiarity could serve as an interpretative guidance in the interpretation of norms different regulatory levels. If the international trade law of universal character does not prejudge its applicability to freshwater and the stateparties interpretation of a regional trade agreement related to the same subject matter seems to exclude it, the interpretation of the universal norm should go in line with the regional indication.

\section{Concluding remarks}

The principle of subsidiarity played a primordial role in the allocation of powers between central (federal) and local (state) authorities. It was noticed as an useful tool in the analysis of states' choices between regional and multilateral legal regimes. The approach proposed in this article opts for its bringing into play as an interpretative guidance tool, similar to the "margin of appreciation" doctrine elaborated by the European Court of Human Rights. The WTO legal regime provides no clear textual indication as to its applicability to trade of bulk water. In the need of filling up a legal lacuna in a multilateral treaty, it is proposed here to do so with an use of the principle of subsidiarity. It would lead to an exclusion of the applicability of the WTO law to the trade of bulk water, as opted by the government of Canada and its NAFTA trading partners.

The international trade in water and water-related products/services becomes a largely discussed and a multidimensional phenomenon. It is tied with a production and trade of electric hydropower and its environmental consequences, trade of "virtual water products", privatization or nationalization of water services. The applicability of 
the principle of subsidiarity to different water-related areas should take place with caution and depend on the specificity of the regulated (or unregulated) object. The choice between uniformity and pluralism in different branches of globalizing legal order must not always be the same. 